\title{
Production behavior and prices of beef cattle in the Brazilian
} Amazon

\section{Comportamento da produção e dos preços de bovinos de corte na Amazônia Brasileira}

\author{
Marcos Antônio Souza dos Santos ${ }^{1 *}$; José de Brito Lourenço Júnior²; Antônio \\ Cordeiro de Santana ${ }^{1}$; Alfredo Kingo Oyama Homma ${ }^{3}$; Cyntia Meireles Martins ${ }^{1}$; \\ Fabrício Khoury Rebello ${ }^{1}$; Bruno Cabral Soares ${ }^{4}$; André Guimarães Maciel e Silva ${ }^{2}$
}

\begin{abstract}
This study evaluates the production behavior and prices in the beef cattle industry in the Brazilian Amazon. We used time series data obtained from various sources and employed multiple regression and polynomial regression analysis. For the price analysis, we used the classical time series model and separated the seasonal and cyclic indices based on the 12-month centered moving average. The analyses covered the period from 1990 to 2015 , when the regional cattle population grew at a rate of $5 \%$ per year, compared to the national growth rate of $1.7 \%$. The price analysis reveals the existence of cycles in regional cattle ranching, defined mainly by an inverse correlation between the price of fattened cattle and the slaughter of matrices. As for the variables determining the growth of the cattle population, we find that rural credit policy assumes an important role in enabling the supply of resources for financing livestock projects that are more popular than investments in agriculture. The creation and structuring of state agricultural defense agencies in the late 1990s represents an important measure in the institutional sphere, as the implementation of animal health policies and programs has generated a favorable environment for the expansion of investments in meat production and processing, in addition to opening up opportunities for trade in the domestic and international markets.
\end{abstract}

Key words: Amazon. Price analysis. Beef cattle ranching. Rural credit. Market.

\section{Resumo}

O artigo avalia o comportamento da produção e dos preços no mercado da pecuária de corte da Amazônia brasileira. Utilizaram-se dados de séries temporais obtidos em diversas fontes e submetidos às análises de regressão múltipla e regressão polinomial. Para a análise de preços utilizou-se o modelo clássico de séries temporais com a separação dos índices sazonais e cíclicos com base na média móvel centrada em doze meses. As análises abrangem o período de 1990 a 2015, fase em que o rebanho bovino regional evoluiu a uma taxa de $5 \%$ ao ano, frente a um crescimento de $1,7 \%$ do rebanho nacional. A

1 Profs. Drs., Instituto Socioambiental e dos Recursos Hídricos da Universidade Federal Rural da Amazônia, ISARH-UFRA, Belém, PA, Brasil. E-mail: marcos.santos@ufra.edu.br; acsufra@gmail.com; cyntiamei@hotmail.com; fabriciorebello@ hotmail.com

2 Profs. Drs., Programa de Pós-Graduação em Ciência Animal, Instituto de Medicina Veterinária da Universidade Federal do Pará, IMV-UFPA, Castanhal, PA, Brasil. E-mail: joselourencojr@yahoo.com.br; andregms@gmail.com

3 Pesquisador, Dr., Empresa Brasileira de Pesquisa Agropecuária, EMBRAPA Amazônia Oriental, Belém, PA, Brasil. E-mail: alfredo.homma@embrapa.br

4 Prof. Dr., Universidade Federal Rural da Amazônia, UFRA, Campus Paragominas, Paragominas, PA, Brasil. E-mail: brunocs@ veterinario.med.br

* Autor correspondente 
análise de preços revelou a existência de ciclos na pecuária bovina regional, definidos, principalmente, pela correlação inversa entre o preço do boi gordo e o abate de matrizes. Quanto às análises das variáveis determinantes do crescimento da produção, configurado na expansão do rebanho, constatouse que a política de crédito rural assumiu papel importante ao viabilizar a oferta de recursos para o financiamento de projetos pecuários que ganharam espaço frente aos investimentos em agricultura. A criação e estruturação das agências estaduais de defesa agropecuária, a partir do final da década de 1990, representou avanço importante na esfera institucional, pois ao executarem as políticas e programas de sanidade animal tem gerado um ambiente favorável para a expansão dos investimentos na produção e processamento, além de abrir oportunidades para comercialização no mercado interno, nacional e internacional.

Palavras-chave: Amazônia. Análise de preços. Bovinocultura de corte. Crédito rural. Mercado.

\section{Introduction}

Cattle ranching is the second most productive activity in Brazilian agriculture. In 2015, meat and milk production represented $20.1 \%$ of the gross value of the country's agricultural production, surpassed only by soybean cultivation, which accounted for $21.5 \%$, as cited by the Ministry of Agriculture, Livestock, and Supply (MAPA, 2016a). From 1990 to 2015 , the national cattle population grew at a rate of $1.7 \%$ per year resulting in a cattle population of 215.2 million heads in 2015 , which is $21.7 \%$ of the world total, the largest commercial herd in the world according to the Food and Agriculture Organization of the United Nations (FAO, 2016).

This growth in cattle population has led to an increase in meat production and export. In the early 1980s, Brazil was not prominent in international beef trade mainly due to sanitary problems (YARDLEYPODOLSKY, 1981). Since the mid-1990s, the national economic development agenda has favored the development of cattle ranching. Trade liberalization, adoption of technological innovations in production systems, advances in health policies, and establishment of slaughterhouses has boosted the growth of cattle ranching in the country (SANTOS et al., 2017).

Meat production also found a more favorable international market owing to increased consumer demand focusing on the health and origin of animals due to the outbreak of diseases like footand-mouth disease (FMD) and mad cow disease in
Europe, the United States, and Canada (SANTOS et al., 2007). Since mad cow disease is associated with the recycling of meat, bones, blood, and viscera and their use in animal feed, this was an opportunity for the Brazilian meat industry as their cattle is grassfed. Moreover, the cattle population in many of the major European countries was decimated in the late 1990s and early 21 st century. Hence, in 2004, Brazil became the world's largest meat exporter, a position it continues to maintain owing to improvements in meat quality (MOITA; GOLANI, 2014).

In this context, the Amazon gained prominence in the growth of national cattle ranching, with a cattle population of 84.2 million heads, accounting for $39.1 \%$ of the national total. Between 1990 and 2015, cattle ranching in Amazon grew at a rate of $5 \%$ per year, well above the national growth rate of $1.7 \%$ per year (Brazilian Institute of Geography and Statistics) (IBGE, 2016b). The beef industry in Amazon has also expanded and now accounts for a third of the total slaughterhouses registered with the Federal Inspection System (Sistema de Inspeção Federal-SIF) in Brazil (IBGE, 2016c).

The general objective of this study is to evaluate the production behavior and prices in beef cattle ranching in the Brazilian Amazon from 1990 to 2015. Specifically, the objective is to evaluate the effects of economic, environmental, and institutional variables determining the cattle population growth in the region and identify the trends, seasonality, and price cycles in regional cattle ranching. 


\section{Methodology}

\section{Study area and data}

The study area is the Legal Amazon, referred to in the article as the Brazilian Amazon, which is composed of Northern states (Acre, Amapá, Amazonas, Pará, Rondônia, Roraima, and Tocantins), the state of Mato Grosso, and the municipalities of the state of Maranhão located west of the $44^{\circ}$ meridian. It has 775 municipalities and occupies an area of approximately 5 million $\mathrm{km}^{2}, 61 \%$ of the total Brazilian territory (IBGE, 2016 a) with a population of 27.9 million, $13.4 \%$ of the national population. This region has $39.1 \%$ of the national cattle population, 84.2 million heads (IBGE, 2016a,b). Cattle ranching in Amazon is spread over 47.98 million hectares of pasture land, accounting for approximately $63 \%$ of agricultural land use in the region (ALMEIDA et al., 2016; Instituto Nacional de Pesquisas Espaciais-INPE, 2016a).

The study covers the period from 1990 to 2015, a phase of expansion in cattle ranching, marked by an increase in environmental problems like deforestation and significant institutional changes in financing and animal health protection.

Time series data were collected from several official sources. The cattle population size and the total cattle slaughtered under inspection were sourced from the Brazilian Institute of Geography and Statistics (IBGE, 2016c). The deforestation rate was sourced from the database of the Legal Amazon Deforestation Monitoring System of the National Institute for Space Research (INPE, 2016b). The price of fattened cattle in the Amazon was calculated from the average prices received by cattle ranchers in the states of Mato Grosso, Maranhão, Pará, Rondônia, and Tocantins, sourced from the Brazilian Cattle Ranching Yearbook (ANUALPEC, 2015). The balances of rural credit operations (agricultural and livestock) were sourced from the Central Bank of Brazil (BACEN, 2016). Fattened cattle prices and balances of rural credit operations were corrected using the General Index of Prices-Internal Availability (Índice Geral de Preços Disponibilidade Interna-IGP-DI), December 2015 (FGV, 2016).

\section{Analysis models}

The growth of beef ranching in the Amazon is a result of the interaction of environmental, economic, and institutional variables that influence the decision making of producers and other economic agents in the production chain (SANTOS et al., 2007). The study period is marked by increased deforestation, expansion in rural credit supply through the Constitutional Funds for Financing the North, Northeast, and Midwest regions (FNO, FNE, and FCO), and the creation of agricultural defense agencies in all states. The following econometric model is used to assess the effect of deforestation, rural credit, and the creation of agricultural defense agencies on the growth of the cattle population:

$C A T H_{t}=a_{0}+a_{1} R C_{t}+a_{2} D R M_{t-2}+a_{3} D V_{t}+e_{t}$

where:

$\mathrm{CATH}_{t}$ denotes the natural logarithm of the Amazon cattle population from 1990 to 2015;

$R C_{t}$ denotes the natural logarithm of the balance of rural credit operations in cattle ranching in the Amazon, in R\$, from 1990 to 2015;

$D R M_{t-2}$ denotes the lagged deforestation rate in two periods, in percentage, from 1990 to 2015;

$D V_{t}$ denotes the dummy variable included in the model to capture the effect of the creation of state agencies of agricultural defense. It has a value of 0 during 1990-1997, and a value of 1 during 19982015; and

$e_{t}$ denotes the random error term.

The hypothesis that we will test is that all coefficients are positive since the increase in the supply of credit and the creation of agencies generate a favorable business environment for 
investments in livestock projects. The correlation between deforestation and cattle population growth is direct, but the effect should take place with a time lag because deforestation initially affects the timber market, and only later are the deforested areas used in agricultural production (RIVERO et al., 2009; SANTANA et al., 2011).

Price analysis is performed using the classical time series decomposition model, which assumes that a historical price series can be decomposed into four basic components: (a) trend, (b) cycle, (c) seasonality, and (d) random variations (SANTANA, 2003; MENDES; PADILHA JUNIOR, 2007; ROSSI; NEVES, 2014). Considering the original series of real prices of fattened cattle, the model is mathematically specified below:

$$
P_{t}=T_{t} \times C_{t} \times S_{t} \times E_{t}
$$

where:

$P t$ denotes the price of fattened cattle in month t in R\$/@;

$T t$ denotes the trend of the time series in period $t$;

$C t$ denotes the cyclical variation in the time series in period $t$;

$S_{t}$ denotes the seasonal variation in the time series in period $t$; and

Et denotes the random variations.

The trend of real prices is estimated using polynomial regression. From a previous visualization of the behavior of data, the best adjustment model is a third-degree polynomial:

$$
\hat{Y}_{i t}=a_{0}+a_{1} t+a_{2} t^{2}+a_{3} t^{3}+e_{t}
$$

where:

$\hat{Y}_{\dot{t} t}$ denotes the estimated value of the price of fattened cattle that reflects the trend in month $\mathrm{i}$ in year $\mathrm{t}$;

$t$ denotes the trend variable, with the following values $(T=0$, for $1990, \ldots \ldots, T=25$, for 2015$)$; $a_{0}$ denotes the intercept of the function that represents the average price in the analyzed period;

$a_{i}$ denotes the angular coefficients of the function; and

$e_{t}$ denotes the random error term.

The seasonal price indices that represent the harvest and inter-harvest periods of cattle ranching are determined using the 12-month centered moving average method, and their fluctuations quantified using the standard deviation and the coefficient of variation (SANTANA, 2003; MENDES; PADILHA JUNIOR, 2007). The cyclic index is calculated by dividing the moving average by the trend value for each month.

All data are stored in LibreOffice spreadsheets and then exported and analyzed in the GNU Regression, Econometrics, and Time-series Library (Gretl) statistical software by the Free Software Foundation (FSF, 2017).

\section{Results and Discussion}

\section{Production behavior}

From 1990 to 2015, the Amazon led the growth in national livestock with a growth rate of $5 \%$ per year, while the national cattle population grew at a rate of only $1.7 \%$ per year. Among other large Brazilian regions, only the Midwest has shown a growth rate higher than the national average (2\% per year). In all other regions, the cattle population remained stable, and the growth rates were less than $1 \%$ per year (IBGE, 2016b).

In this period, all Amazon states recorded rates higher than the national growth rate. The cattle population in Amapá, Amazonas, Maranhão, Roraima, and Tocantins more than doubled; in Mato Grosso and Pará, it more than trebled; and in Acre, 
it increased by 7.3 times. Rondônia registered a cattle population growth of 7.8 times, and currently accounts for $15.9 \%$ of the regional cattle population, when in 1990, it accounted for only $6.5 \%$.

Currently, the states with the largest cattle concentration in the region are Mato Grosso (34.9\%),
Pará (24.1\%), Rondônia (15.9\%), Tocantins (10\%), and Maranhão (9.1\%). The states of Acre, Amapá, Roraima, and Amazonas, together, account for only $6 \%$ of the national cattle population, at 5.2 million heads (Table 1).

Table 1. Distribution and growth of Brazilian cattle population, in thousand heads (1990-2015).

\begin{tabular}{|c|c|c|c|c|c|c|c|c|c|}
\hline \multirow{2}{*}{$\begin{array}{c}\text { Year } \\
\text { Region/State }\end{array}$} & \multicolumn{2}{|c|}{1990} & \multicolumn{2}{|c|}{2000} & \multicolumn{2}{|c|}{2010} & \multicolumn{2}{|c|}{2015} & GGR \\
\hline & Quant. & $\%$ & Quant. & $\%$ & Quant. & $\%$ & Quant. & $\%$ & $\%$ per year \\
\hline North & 13,663 & 9.27 & 24,518 & 14.43 & 42,101 & 20.09 & 47,155 & 21.91 & $5.40 *$ \\
\hline Rondônia & 1,719 & 1.17 & 5,664 & 3.33 & 11,842 & 5.65 & 13,398 & 6.23 & $7.88^{*}$ \\
\hline Acre & 400 & 0.27 & 1,033 & 0.61 & 2,578 & 1.23 & 2,916 & 1.36 & $9.57 *$ \\
\hline Amazonas & 637 & 0.43 & 843 & 0.50 & 1,361 & 0.65 & 1,293 & 0.60 & $3.80^{*}$ \\
\hline Roraima & 346 & 0.23 & 480 & 0.28 & 577 & 0.28 & 795 & 0.37 & $3.49 *$ \\
\hline Pará & 6,182 & 4.19 & 10,271 & 6.05 & 17,633 & 8.42 & 20,272 & 9.42 & $5.45^{*}$ \\
\hline Amapá & 70 & 0.05 & 83 & 0.05 & 115 & 0.05 & 79 & 0.04 & $2.83^{*}$ \\
\hline Tocantins & 4,309 & 2.92 & 6,142 & 3.62 & 7,994 & 3.82 & 8,402 & 3.90 & $2.71 *$ \\
\hline Northeast & 26,190 & 17.76 & 22,567 & 13.28 & 28,762 & 13.73 & 29,092 & 13.52 & $0.96 *$ \\
\hline Maranhão & 3,900 & 2.65 & 4,094 & 2.41 & 6,980 & 3.33 & 7,643 & 3.55 & $3.49^{*}$ \\
\hline Piauí & 1,974 & 1.34 & 1,779 & 1.05 & 1,680 & 0.80 & 1,650 & 0.77 & $-0.79 *$ \\
\hline Ceará & 2,621 & 1.78 & 2,206 & 1.30 & 2,546 & 1.22 & 2,516 & 1.17 & $0.38 * *$ \\
\hline Rio Grande do Norte & 956 & 0.65 & 804 & 0.47 & 1,065 & 0.51 & 919 & 0.43 & $1.04 *$ \\
\hline Paraíba & 1,345 & 0.91 & 953 & 0.56 & 1,243 & 0.59 & 1,171 & 0.54 & $0.05 \mathrm{~ns}$ \\
\hline Pernambuco & 1,966 & 1.33 & 1,516 & 0.89 & 2,383 & 1.14 & 1,948 & 0.91 & $1.30 *$ \\
\hline Alagoas & 891 & 0.60 & 779 & 0.46 & 1,220 & 0.58 & 1,256 & 0.58 & $1.83^{*}$ \\
\hline Sergipe & 1,030 & 0.70 & 880 & 0.52 & 1,118 & 0.53 & 1,231 & 0.57 & $1.16^{*}$ \\
\hline Bahia & 11,505 & 7.80 & 9,557 & 5.63 & 10,528 & 5.02 & 10,758 & 5.00 & $0.07 \mathrm{~ns}$ \\
\hline Southeast & 36,323 & 24.63 & 36,852 & 21.69 & 38,252 & 18.26 & 38,812 & 18.04 & $0.27 *$ \\
\hline Minas Gerais & 20,472 & 13.88 & 19,975 & 11.76 & 22,698 & 10.83 & 23,769 & 11.05 & $0.72 *$ \\
\hline Espírito Santo & 1,665 & 1.13 & 1,825 & 1.07 & 2,195 & 1.05 & 2,224 & 1.03 & $1.09^{*}$ \\
\hline Rio de Janeiro & 1,924 & 1.30 & 1,959 & 1.15 & 2,161 & 1.03 & 2,351 & 1.09 & $0.86^{*}$ \\
\hline São Paulo & 12,263 & 8.32 & 13,092 & 7.71 & 11,198 & 5.34 & 10,468 & 4.86 & $-0.82 *$ \\
\hline South & 25,326 & 17.18 & 26,298 & 15.48 & 27,866 & 13.30 & 27,435 & 12.75 & $0.36^{*}$ \\
\hline Paraná & 8,617 & 5.84 & 9,646 & 5.68 & 9,411 & 4.49 & 9,315 & 4.33 & $0.28 * *$ \\
\hline Santa Catarina & 2,994 & 2.03 & 3,051 & 1.80 & 3,986 & 1.90 & 4,382 & 2.04 & $1.65^{*}$ \\
\hline Rio Grande do Sul & 13,715 & 9.30 & 13,601 & 8.01 & 14,469 & 6.91 & 13,737 & 6.38 & $0.09 \mathrm{~ns}$ \\
\hline Midwest & 45,946 & 31.16 & 59,641 & 35.11 & 72,560 & 34.63 & 72,706 & 33.79 & $1.89^{*}$ \\
\hline Mato Grosso do Sul & 19,164 & 13.00 & 22,205 & 13.07 & 22,354 & 10.67 & 21,357 & 9.92 & $0.26 \mathrm{~ns}$ \\
\hline Mato Grosso & 9,041 & 6.13 & 18,925 & 11.14 & 28,757 & 13.72 & 29,364 & 13.65 & $4.88^{*}$ \\
\hline Goiás & 17,635 & 11.96 & 18,399 & 10.83 & 21,348 & 10.19 & 21,888 & 10.17 & $0.96^{*}$ \\
\hline Distrito Federal & 106 & 0.07 & 112 & 0.07 & 101 & 0.05 & 97 & 0.04 & $-0.79 *$ \\
\hline Brazil & 147,448 & 100.00 & 169,876 & 100.00 & 209,541 & 100.00 & 215,199 & 100.00 & $1.70 \%$ \\
\hline
\end{tabular}

Notes: TGC $=$ Geometric Growth Rate determined by linear regression. $\left({ }^{*}\right)$ and $(* *)$ indicate significance at the $1 \%$ and $5 \%$ levels, respectively, based on the student's t-test. (ns) not significant.

Source: IBGE (2016b). 
The growth in cattle population in the Amazon practically no change in the total number of plants has caused significant changes in the spatial in the country. However, the number of plants in distribution of the slaughter agribusiness in Brazil. the Amazon more than doubled from 35 in 1997 to Table 2 shows the state-wise and region-wise 72 in 2015. This represents 33\% of the total beef distribution of slaughterhouses registered with processing parks.

SIF from 1997 to 2015. In this period, there was

Table 2. Cattle slaughter plants under federal inspection (SIF) (1997, 2000, 2010 and 2015).

\begin{tabular}{|c|c|c|c|c|c|c|c|c|}
\hline \multirow{2}{*}{$\begin{array}{c}\text { Year } \\
\text { Region/State }\end{array}$} & \multicolumn{2}{|c|}{1997} & \multicolumn{2}{|c|}{2000} & \multicolumn{2}{|c|}{2010} & \multicolumn{2}{|c|}{2015} \\
\hline & Quant. & $\%$ & Quant. & $\%$ & Quant. & $\%$ & Quant. & $\%$ \\
\hline North & 15 & 6.82 & 23 & 10.50 & 42 & 19.00 & 40 & 18.35 \\
\hline Rondônia & 3 & 1.36 & 6 & 2.74 & 15 & 6.79 & 13 & 5.96 \\
\hline Acre & 1 & 0.45 & 1 & 0.46 & 3 & 1.36 & 2 & 0.92 \\
\hline Amazon & 0 & 0.00 & 1 & 0.46 & 2 & 0.90 & 1 & 0.46 \\
\hline Roraima & 1 & 0.45 & 1 & 0.46 & 1 & 0.45 & 1 & 0.46 \\
\hline Pará & 4 & 1.82 & 8 & 3.65 & 14 & 6.33 & 14 & 6.42 \\
\hline Amapá & 0 & 0.00 & 0 & 0.00 & 0 & $0.00-$ & 0 & 0.00 \\
\hline Tocantins & 6 & 2.73 & 6 & 2.74 & 7 & 3.17 & 9 & 4.13 \\
\hline Northeast & 16 & 7.27 & 13 & 5.94 & 8 & 3.62 & 13 & 5.96 \\
\hline Maranhão & 4 & 1.82 & 3 & 1.37 & 2 & 0.90 & 4 & 1.83 \\
\hline Piauí & 0 & 0.00 & 0 & 0.00 & 0 & 0.00 & 0 & 0.00 \\
\hline Ceará & 1 & 0.45 & 0 & 0.00 & 0 & 0.00 & 0 & 0.00 \\
\hline Rio Grande do Norte & 2 & 0.91 & 1 & 0.46 & 1 & 0.45 & 0 & 0.00 \\
\hline Paraíba & 2 & 0.91 & 0 & 0.00 & 0 & 0.00 & 0 & 0.00 \\
\hline Pernambuco & 1 & 0.45 & 1 & 0.46 & 0 & 0.00 & 0 & 0.00 \\
\hline Alagoas & 1 & 0.45 & 3 & 1.37 & 0 & 0.00 & 0 & 0.00 \\
\hline Sergipe & 0 & 0.00 & 0 & 0.00 & 1 & 0.45 & 1 & 0.46 \\
\hline Bahia & 5 & 2.27 & 5 & 2.28 & 4 & 1.81 & 8 & 3.67 \\
\hline Southeast & 70 & 31.82 & 61 & 27.85 & 63 & 28.51 & 59 & 27.06 \\
\hline Minas Gerais & 27 & 12.27 & 27 & 12.33 & 32 & 14.48 & 34 & 15.60 \\
\hline Espírito Santo & 2 & 0.91 & 4 & 1.83 & 4 & 1.81 & 3 & 1.38 \\
\hline Rio de Janeiro & 2 & 0.91 & 1 & 0.46 & 1 & 0.45 & 0 & 0.00 \\
\hline São Paulo & 39 & 17.73 & 29 & 13.24 & 26 & 11.76 & 22 & 10.09 \\
\hline South & 53 & 24.09 & 50 & 22.83 & 35 & 15.84 & 29 & 13.30 \\
\hline Paraná & 21 & 9.55 & 18 & 8.22 & 15 & 6.79 & 14 & 6.42 \\
\hline Santa Catarina & 5 & 2.27 & 7 & 3.20 & 5 & 2.26 & 4 & 1.83 \\
\hline Rio Grande do Sul & 27 & 12.27 & 25 & 11.42 & 15 & 6.79 & 11 & 5.05 \\
\hline Midwest & 66 & 30.00 & 72 & 32.88 & 73 & 33.03 & 77 & 35.32 \\
\hline Mato Grosso do Sul & 25 & 11.36 & 27 & 12.33 & 25 & 11.31 & 29 & 13.30 \\
\hline Mato Grosso & 16 & 7.27 & 22 & 10.05 & 29 & 13.12 & 28 & 12.84 \\
\hline Goiás & 25 & 11.36 & 23 & 10.50 & 19 & 8.60 & 20 & 9.17 \\
\hline Distrito Federal & 0 & 0.00 & 0 & 0.00 & 0 & 0.00 & 0 & 0.00 \\
\hline Brazil & 220 & 100.00 & 219 & 100.00 & 221 & 100.00 & 218 & 100.00 \\
\hline
\end{tabular}

Source: IBGE (2016c). 
As for the state-wise distribution, the six beef processing parks are in Minas Gerais, Mato Grosso do Sul, Mato Grosso, São Paulo, Goiás, and Pará, which together account for $67.43 \%$ of the slaughter companies in Brazil. Rondônia and Tocantins have also shown considerable growth (Table 2).

The expansion in the regional meat processing industry made it possible to the increase the scale of slaughter inspection, which led to an improvement in the meat quality for the domestic market and export.
Figure 1 shows the growth in the total number of cattle slaughtered in the Amazon and Brazil between 1997 and 2015. In this period, the national growth rate of slaughterhouses was $4.8 \%$ per year, while in the Amazon, it was 9.3\% per year. In 2015, the number of animals officially slaughtered in the Amazon was 11.7 million heads, 5.5 times higher than in 1997 , corresponding to $38.1 \%$ of the total number of animals slaughtered in the country. In 1997 , this share was only $14.3 \%$.

Figure 1. Growth in official slaughter of cattle in Brazil and the Brazilian Amazon (1997-2015).

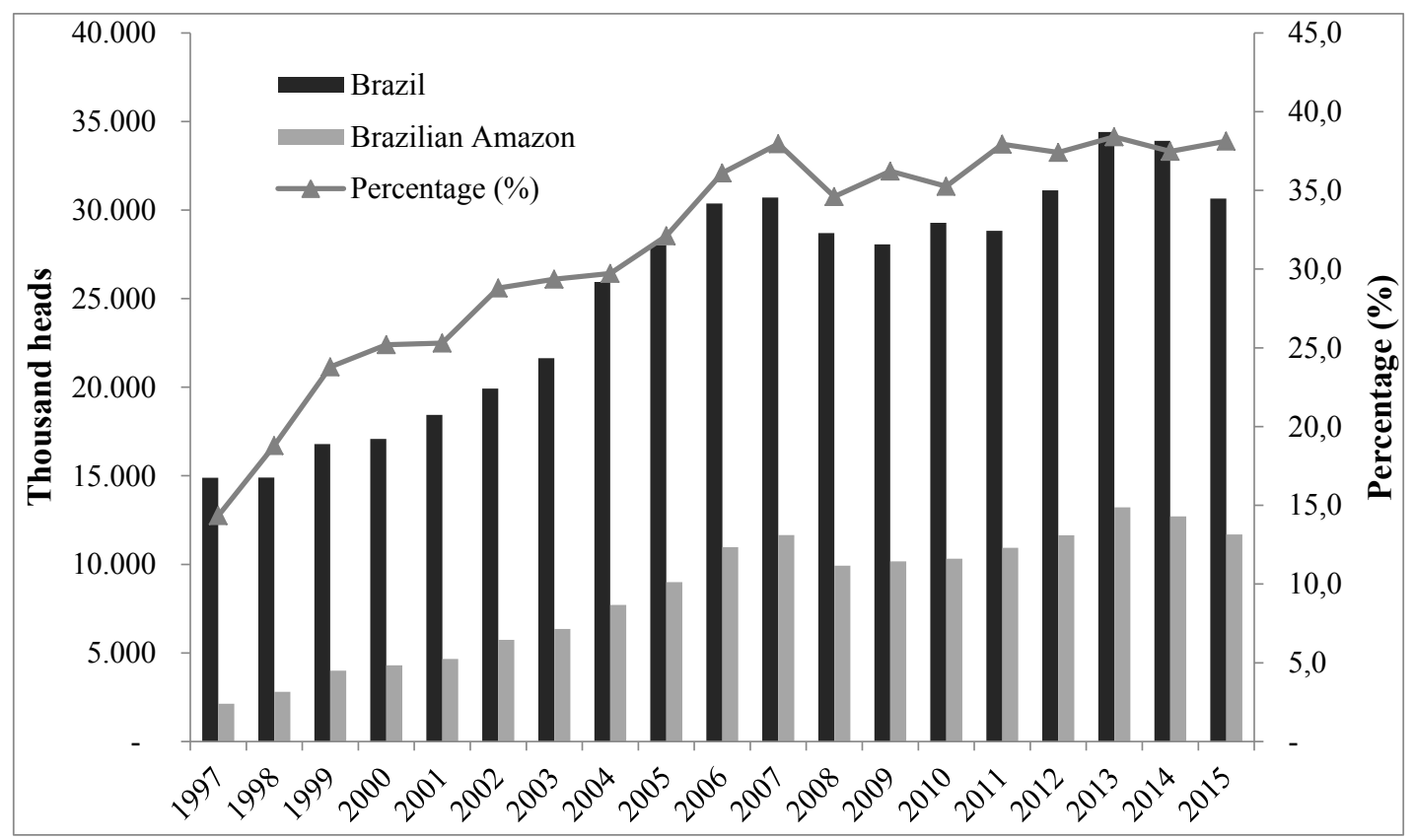

The econometric model in Table 3 estimates the effects of environmental and institutional variables on the growth of cattle population in the Amazon. The F-test is significant at the $1 \%$ level; the determination coefficient indicates that $95.27 \%$ of the total variation in the cattle population is due to variations in the independent variables (balances of rural credit operations, deforestation rate lagged for two periods, and the dummy variable used to capture the effect of the creation of agricultural defense agencies). There is no serial correlation in the residues, as measured using the DurbinWatson test. There is also no multicollinearity since the inflationary variance factor of all independent variables is less than 10. All coefficients are significant at the $1 \%$ level as determined by the student's t-test. 
Table 3. Results of econometric adjustment of the cattle population equation in the Brazilian Amazon (1990-2015).

\begin{tabular}{lccc}
\hline \multicolumn{1}{c}{ Variable } & Coefficient & Standard Error & T-test \\
\hline Constant & $11.9249^{*}$ & 0.8451 & 14.1103 \\
Rural Credit $(R C t)$ & $0.4852^{*}$ & 0.0527 & 9.2542 \\
Deforestation $(D R M t-2)$ & $0.1777^{*}$ & 0.0535 & 3.3245 \\
Dummy $(D V t)$ & $0.2580^{*}$ & 0.0586 & 4.4029 \\
R-square & 0.9527 & & \\
Adjusted R-square & 0.9462 & & \\
F Test & $147.5629^{*}$ & & \\
Durbin-Watson & 1.7649 & & \\
\hline
\end{tabular}

Notes: (ns) indicates the value is not significant; $(*)$ indicates significance at the $1 \%$ level.

An important instrument to support the growth of cattle ranching in the Brazilian Amazon is the rural credit policy. In the last 20 years, there has been substantial progress in the allocation of resources for livestock projects, mainly with offer of resources from the FNO, FNE, and FCO, among others (CAMPOS; SANTOS, 2013). The coefficient of the credit variable is 0.4852 , and since the model is specified logarithmically, it can be interpreted as credit elasticity. Thus, a 10\% increase in the supply of credit implies an increase of $4.852 \%$ in the number of cattle, ceteris paribus.

The change in the profile of rural credit applications over the analyzed period is significant. In the beginning of the $1990 \mathrm{~s}, 82.44 \%$ of the resources were allocated to agricultural projects; by 2015, this percentage dropped to $45.47 \%$. Credit for cattle ranching projects increased from $17.56 \%$ in 1990 to $54.53 \%$ in 2015 . In this period, there was an increase of $4.1 \%$ in the balances of rural credit operations, determined by the growth of investments in livestock, which grew at a rate of $10.2 \%$ per year (BACEN, 2016).

The state with the largest share of resources allocated to livestock is Mato Grosso, with $42.01 \%$ in 2015, followed by Rondônia, Tocantins, and Pará. All states have recorded growth in resource allocation between 1995 and 2015. The state with the highest growth rate is Rondônia $(21.1 \%$ per year), followed by Acre (21\%), Tocantins (19.3\% per year), and Pará (11.4\% per year).
The deforestation rate lagged in two periods shows a direct and significant relationship with the cattle population. The coefficient of elasticity of 0.1777 indicates that an increase of $10 \%$ in deforestation with a lag of two years causes an increase of $1.777 \%$ in the cattle population. That is, deforestation is a variable that shifts the supply curve of cattle to the right (Table 3 ).

There has been tremendous improvement in hygiene policies in the Amazon from the second half of the 1990s, with the creation of state agencies for agricultural defense. Until 1998, only the state of Mato Grosso had a defense agency, established in 1979. The others were set up in 1998 (Tocantins), 1999 (Rondônia), 2002 (Amapá, Maranhão, and Pará), 2003 (Acre), 2008 (Roraima), and 2012 (Amazonas) (MAPA, 2016b). The coefficient of the dummy variable, included in the model to capture the effect of the creation of state agricultural defense agencies, is positive and significant, which shows its importance for regional livestock. These agencies are responsible for implementing national animal health policies in accordance with the guidelines of the World Organization for Animal Health (OIE), with emphasis on the National Program for the Eradication and Prevention of Foot-andMouth Disease (Programa Nacional de Erradicação e Prevenção da Febre Aftosa-PNEFA) and the National Program for the Control and Eradication of Animal Brucellosis and Tuberculosis (Programa Nacional de Controle e Erradicação da Brucelose e Tuberculose Animal-PNCEBT). 
The most significant achievement of these agencies is the eradication of FMD in the country and, particularly, in the Brazilian Amazon. In 2000, the state of Mato Grosso was recognized as a FMDfree area due to vaccination. Tocantins achieved the same recognition in 2001, Rondônia in 2003, Acre and two municipalities in the state of Amazonas in 2005, the Southeast of the state of Pará in 2007, the FMD-free area in Amazonas was expanded in 2011; and, the state of Maranhão and North of the state of Pará were declared FMD-free in 2014 (MAPA, 2016b). In the second half of 2015, 79.7 million heads of cattle and buffalo were vaccinated in the Brazilian Amazon, a 97.07\% coverage rate (MAPA, 2016c).

\section{Price behavior}

The price of fattened cattle is the main economic variable that influences cattle production. It acts as a reference for the decision making of cattle ranchers and causes price changes in the other phases of cattle ranching breeding, rearing, and fattening. It also influences the dynamics of slaughter in slaughterhouses.

The evaluation of price behavior of fattened cattle requires the identification of three basic movements: trends, cycles, and seasonality. A trend is a long-term movement and, in the case of beef cattle/, results from productivity gains associated with technological innovations, structural changes in the market, and public policies to promote production (MENDES; PADILHA JUNIOR, 2007).

Fattened cattle prices also show multi-annual movements of growth and decline, where a fall in the price of fattened cattle causes a decrease in the prices of intermediate categories and an increase in the rate of disposal of matrices (SACHS; PINATTI, 2013). The increase in the slaughter of matrices, in turn, generates a glut of beef immediately and a scarcity of fattened cattle in the future, causing prices to fall. Balance can be restored only when a reduction in the availability of fattened cattle is sufficient to force an increase in meat prices. This movement is called the livestock cycle, and its knowledge is important for producers and other economic agents in the beef cattle production chain, for planning.

Seasonal movements take place in the short term and are related to weather conditions that define harvest and inter-harvest periods in a year. In the case of cattle, the seasonality of prices is associated with a greater or lesser supply of animals for slaughter that depends, given the hegemony of the pasture production system, on the quality and availability of pastures throughout the year.

Figure 2 shows the behavior of real prices received by cattle ranchers in the Amazon and the cyclical index for the period from January 1990 to December 2016. The lowest prices were observed in 1997 and 2006 that marked the lowest points of the livestock cycles of the 1990s and 2000s. From 2006 onwards, there is a trend towards higher real prices, and the cycles decrease in magnitude compared to the previous decades. From 2015 onwards, prices start declining, leading up to the next low phase of the livestock cycle.

In the domestic market, price behavior of the arroba of fattened cattle is associated with the slaughter of matrices (cows). The inverse relationship between these variables indicates that a change in the price cycle of fattened cattle is caused by the liquidation of the stock of matrices. This impact is reversed in later periods in the scarcity of calves and lean cattle, which decreases the supply of fattened cattle and, later, forces a reaction in prices (Figure 3).

In 2004, 7.7 million heads of cattle were slaughtered in the Amazon; of this, 37.5\% were females. In 2005, there was a growth of $16.8 \%$ in total slaughters, reaching 9 million heads. However, this growth was strongly conditioned by an increase in the slaughter of matrices that had grown from 
$34.7 \%$ in the previous year to $43.2 \%$ of the total number of animals slaughtered. This process reached its peak in 2006 when the slaughter rate of matrices was $46.1 \%$, and the prices of fattened cattle reached their lowest level in the analyzed period (Figure 3).

Figure 2. Price behavior of fattened cattle in the Brazilian Amazon (1995-2016).

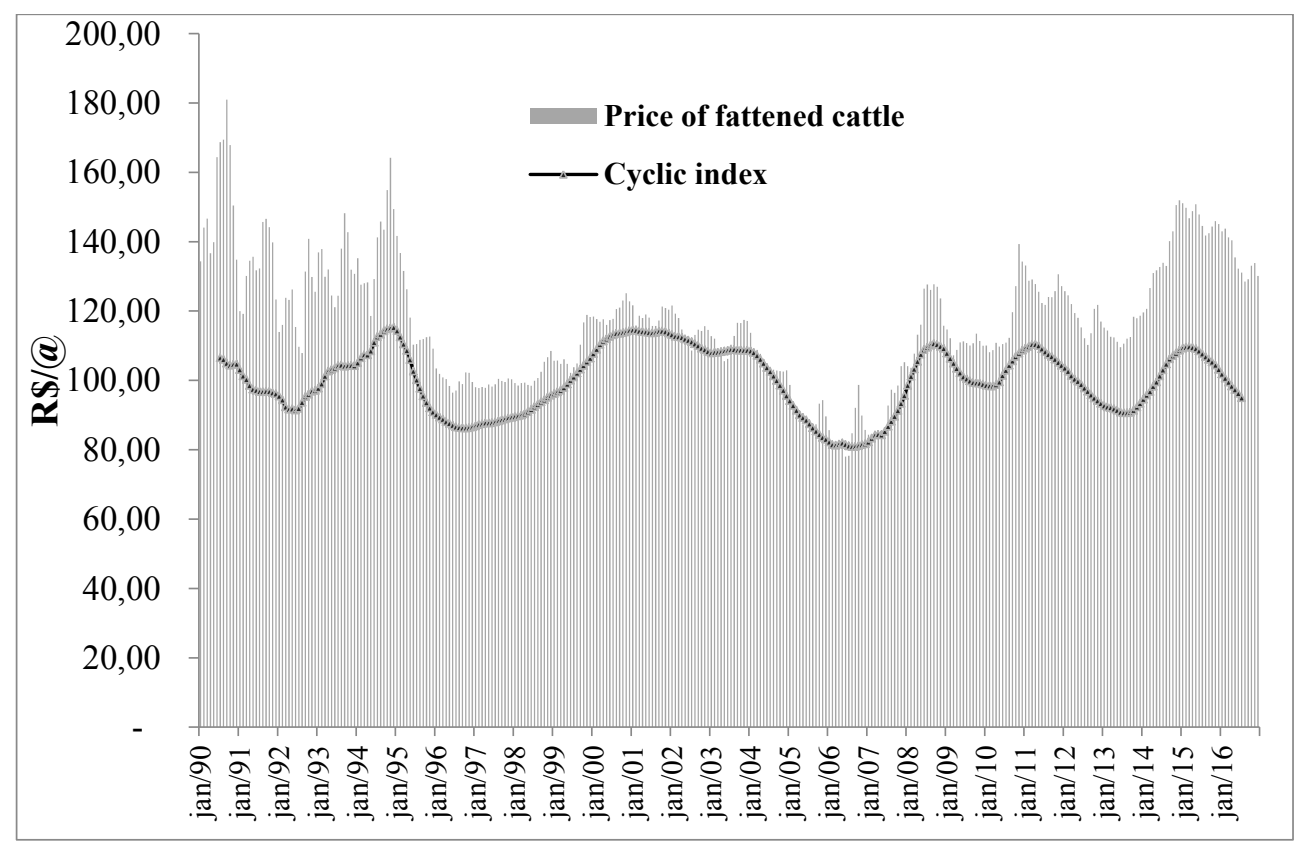

Figure 3. Growth in the price of fattened cattle and slaughter of cows in the Brazilian Amazon (2004-2016).

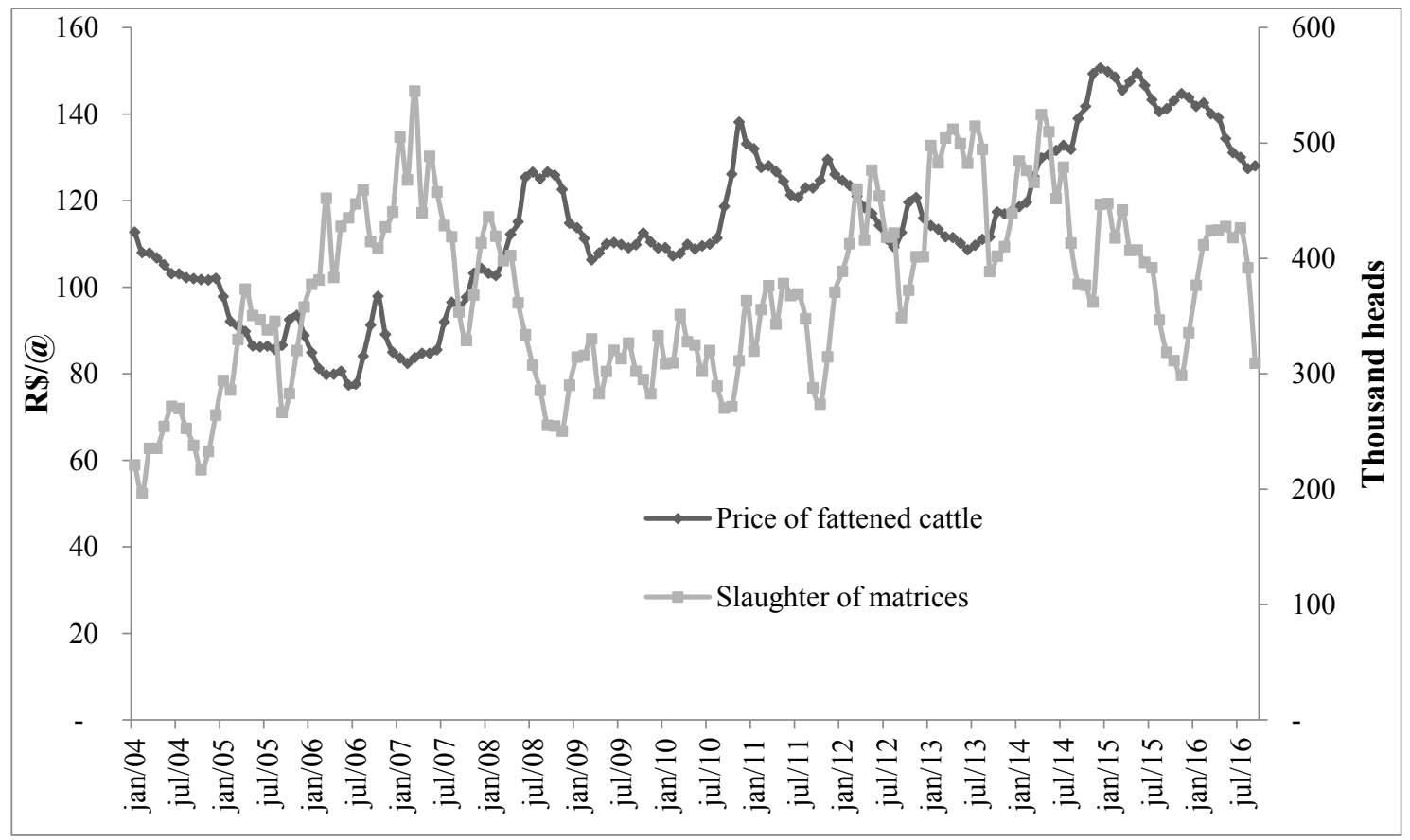


In the Amazon, the prices of fattened cattle also show a seasonal behavior, which is a characteristic of harvest and inter-harvest periods. Table 4 presents the seasonal price indices received by ranchers. From what is observed, the inter-harvest of fattened cattle in the Amazon is remarkable in the last four months of the year until January of the following year. In this phase, the seasonal indices are greater than 100.00, which is the annual average index.

The amplitude of price variation throughout the year is $6.6 \%$. This indicator is the result of the difference between the highest value of the seasonal index (104.18\%) registered in November and the lowest value (97.58\%) registered in July (Table 4). As the animals are fed on pasture, these fluctuations are conditioned mainly by the availability of forage, defined by rainfall conditions. To assess price variability in each month, the coefficient of variation of the seasonal indices is determined. The values vary from a minimum of $1.98 \%$ in April to a maximum of $3.34 \%$ in October. Generally, there is greater price variability during the second half of the year, when prices reach their highest levels of the year. In the first half of the year, prices are at their lowest levels and variability is lower.

Table 4. Descriptive statistics of seasonal price indices of fattened cattle in the Brazilian Amazon (1995-2016).

\begin{tabular}{lccccc}
\hline \multirow{2}{*}{ Month } & \multicolumn{3}{c}{ Seasonal Indices } & Deviation & CV \\
\cline { 2 - 5 } & Lower Limit & Average & Upper Limit & Standard & $(\%)$ \\
\hline January & 98.63 & 100.82 & 103.02 & 2.19 & 2.18 \\
February & 96.63 & 99.05 & 101.47 & 2.42 & 2.44 \\
March & 96.45 & 98.66 & 100.87 & 2.21 & 2.24 \\
April & 96.91 & 98.87 & 100.83 & 1.96 & 1.98 \\
May & 96.04 & 98.13 & 100.22 & 2.09 & 2.13 \\
June & 94.38 & 97.58 & 100.78 & 3.20 & 3.28 \\
July & 94.35 & 97.60 & 100.86 & 3.26 & 3.33 \\
August & 95.92 & 98.80 & 101.68 & 2.88 & 2.91 \\
September & 97.78 & 100.57 & 103.36 & 2.79 & 2.77 \\
October & 99.83 & 103.28 & 106.73 & 3.45 & 3.34 \\
November & 101.37 & 104.18 & 107.00 & 2.82 & 2.70 \\
December & 100.12 & 102.45 & 104.78 & 2.33 & 2.27 \\
\hline
\end{tabular}

Source: Estimates based on data from ANUALPEC (2015).

\section{Conclusion}

The Amazon has effectively contributed to the growth of Brazilian cattle ranching, since much of the expansion in the cattle population has occurred in this region, mainly in the states of Mato Grosso, Pará, Rondônia, and Tocantins. The number of slaughterhouses has also increased, and the region currently houses a third of the beef slaughterhouses registered with SIF of MAPA.

Rural credit and health protection policies have played an important role in supporting the development of regional cattle ranching. In case of rural credit, there has been a significant change in the profile of the investments in livestock projects as opposed to agriculture, with livestock financing representing $54.53 \%$ of the operations balance in 2015 when they represented only $17.56 \%$ in 1995 . The resources of FCO, FNE, and FCO for stability in credit supply have been significantly important in this context.

The creation of state agricultural defense agencies in the late 1990s and during the first decade of the 21 st century represented an important measure in the institutional sphere, as the implementation of 
animal health policies and programs has generated a favorable environment for the increase in investments in meat production and processing, Moreover, it has opened opportunities for trading in the domestic and international markets.

\section{References}

ALMEIDA, C. A.; COUTINHO, A. C.; ESQUERDO, J. C. D. M.; ADAMI, M.; VENTURIERI, A.; DINIZ, C. G.; DESSAY, N.; DURIEUX, L.; GOMES, A. R. High spatial resolution land use and land cover mapping of the Brazilian Legal Amazon in 2008 using Landsat-5/TM and MODIS data. Acta Amazônica, Manaus, v. 46, n. 3, p. 291-302, 2016. DOI: 10.1590/1809-4392201505504

\section{ANUÁRIO DA PECUÁRIA BRASILEIRA -} ANUALPEC. Anuário Estatístico da Pecuária Brasileira. São Paulo: Informa Economics FNP, 2015. 280 p.

BANCO CENTRAL DO BRASIL - BACEN. ESTBAN. Estatística bancária por município. Brasília: BACEN, 2016. Disponível em: http://www4.bcb.gov.br/fis/cosif/ estban.asp. Acesso em: 5 dez. 2016.

CAMPOS, A. C.; SANTOS, M. A. S. Sistema de indicadores de monitoramento e avaliação do Fundo Constitucional de Financiamento do Norte (FNO). Belém: Banco da Amazônia, 2013. 74 p.

FOOD AGRICULTURE ORGANIZATION OF THE UNITED NATIONS - FAO. Statistical Databases. Rome: FAO, 2016. Available at: http://www.fao.org. Accessed at: 5 dez. 2016.

FREE SOFTWARE FOUNDATION - FSF. Gnu regression, econometrics and time-series library. Boston: FSF, 2017. Available at: http:/gretl.sourceforge.net/ pt.html. Accessed at: 17 fev. 2017.

FUNDAÇÃO GETÚLIO VARGAS - FGV. FGVDADOS: informação econômica on-line. Rio de Janeiro: FGV, 2016. Disponível em: http://fgvdados.fgv.br. Acesso em: 5 dez. 2016.

INSTITUTO BRASILEIRO DE GEOGRAFIA E ESTATÍSTICA - IBGE. Áreas especiais: cadastro de municípios localizados na Amazônia Legal. Rio de Janeiro: IBGE, 2016a. Disponível em: http://www. ibge.gov.br/home/geociencias/geografia/amazonialegal. shtm?c=2. Acesso em: 21 set. 2016.

INSTITUTO BRASILEIRO DE GEOGRAFIA E ESTATÍSTICA - IBGE. Pesquisa pecuária municipal. Rio de Janeiro: IBGE, 2016b. Disponível em: http:// www.sidra.ibge.gov. br. Acesso em: 5 dez. 2016.
INSTITUTO BRASILEIRO DE GEOGRAFIA E ESTATÍSTICA - IBGE. Pesquisa trimestral de abates de animais. Rio de Janeiro: IBGE, 2016c. Disponível em: http://www.sidra.ibge.gov.br. Acesso em: 5 dez. 2016.

INSTITUTO NACIONAL DE PESQUISAS ESPACIAIS - INPE. Levantamento de informações de uso e cobertura da terra na Amazônia - Terraclass. Brasília: INPEEMBRAPA, 2016a. Disponível em: http://www. inpe.br/cra/projetos_pesquisas/dados_terraclass.php. Acesso em: 5 dez. 2016.

INSTITUTO NACIONAL DE PESQUISAS ESPACIAIS - INPE. Projeto PRODES: monitoramento da floresta Amazônica Brasileira por satélite. Brasília: INPE, 2016 b. Disponível em: http://www.obt.inpe.br/ prodes/index. php. Acesso em: 5 dez. 2016.

MENDES, J. T. G.; PADILHA JUNIOR, J. B. Agronegócio: uma abordagem econômica. São Paulo: Pearson Prentice Hall, 2007. 369 p.

MINISTÉRIO DA AGRICULTURA, PECUÁRIA E ABASTECIMENTO - MAPA. Campanhas de vacinação contra febre aftosa. Brasília: MAPA, 2016c. Disponível em: http://www.agricultura.gov.br/febreaftosa. Acesso em: 5 dez. 2016.

MINISTÉRIO DA AGRICULTURA, PECUÁRIA E ABASTECIMENTO - MAPA. Evolução geográfica do processo de implantação de zona livre de febre aftosa no Brasil. Brasília: MAPA, 2016b. Disponível em: http:// www.agricultura.gov.br/febreaftosa. Acesso em: 5 dez. 2016.

MINISTÉRIO DA AGRICULTURA, PECUÁRIA E ABASTECIMENTO - MAPA. Valor bruto da produção agropecuária (VBP). Brasília: MAPA, 2016a. Disponível em: http://www.agricultura.gov.br/ ministerio/gestaoestrategica/valor-bruto-da-producao. Acesso em: $5 \mathrm{dez}$. 2016.

MOITA, R. M.; GOLANI, L. A. Oligopsônio dos frigoríficos: uma análise empírica de poder de mercado. Revista de Administração Contemporânea, Rio de Janeiro, v. 18, n. 6, p. 772-794, 2014. DOI: 10.1590/19827849rac20141196

RIVERO, S.; ALMEIDA, O.; ÁVILA, S.; OLIVEIRA, W. Pecuária e desmatamento: uma análise das principais causas diretas do desmatamento na Amazônia. Nova Economia, Belo Horizonte, MG, v. 19, n. 1, p. 41-66, 2009. DOI: $10.1590 / \mathrm{S} 0103-63512009000100003$

ROSSI, J. W.; NEVES, C. Econometria e séries temporais com aplicações a dados da economia brasileira. Rio de Janeiro: LTC, 2014. 378 p. 
SACHS, R. C.C.; PINATTI, E. Análise do comportamento dos preços do boi gordo e do boi magro na pecuária de corte paulista, no período de 1995 a 2006. Revista de Economia e Agronegócio, Viçosa, MG, v. 5, n. 3, p. 329351, 2013.

SANTANA, A. C. Métodos quantitativos em economia: elementos e aplicações. Belém: UFRA, 2003. 485 p.

SANTANA, A. C.; SANTANA, A. L.; SANTOS, M. A. S. Influência do desmatamento no mercado de madeira em tora da região Mamuru-Arapiuns, Sudoeste do Pará. Revista de Ciências Agrárias, Belém, v. 54, n. 1, p. 4453, 2011.
SANTOS, M. A. S.; LOURENÇO JUNIOR, J. B.; SANTANA, A. C.; HOMMA, A. K. O.; ANDRADE, S. J. T.; SILVA, A. G. M. Caracterização do nível tecnológico da pecuária bovina na Amazônia Brasileira. Revista de Ciências Agrárias, Belém, v. 60, n. 1, p. 103-111, 2017.

SANTOS, M. A. S.; SANTOS, J. S. B.; CUNHA, S. J. T.; SANTANA, A. C. Mercado e dinâmica local da cadeia produtiva da pecuária de corte na Região Norte. Belém: Banco da Amazônia, 2007. 48 p. (Estudos Setoriais, 1).

YARDLEY-PODOLSKY, W. J. H. Um perfil da indústria de carnes e de seu futuro. Revista de Administração de Empresas, São Paulo, v. 21, n. 2, p. 49-58, 1981. DOI: 10.1590/S0034-75901981000200005 
